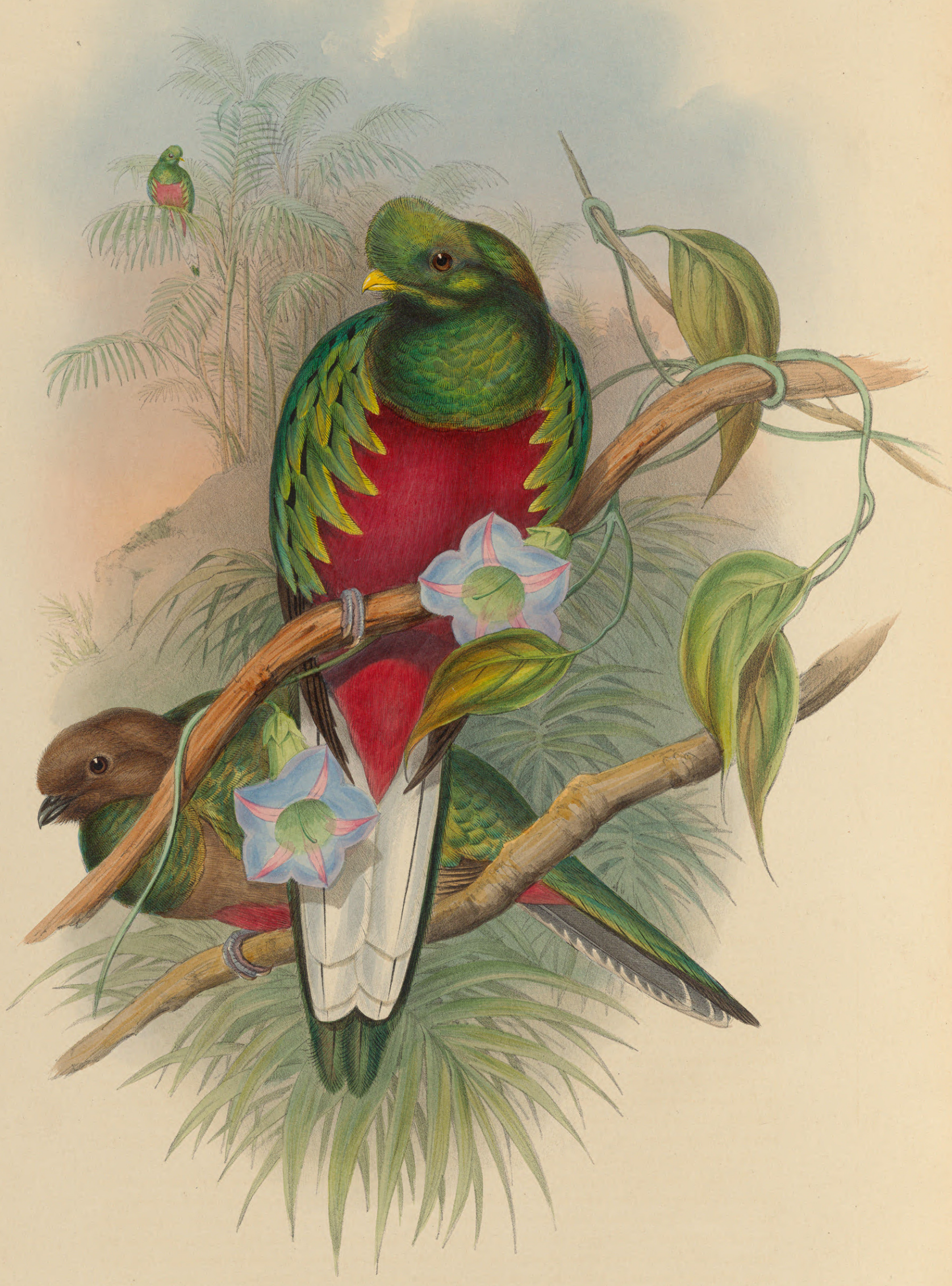




\title{
PHAROMACRUS AN'TISIANUS.
}

\section{Beautiful Train-bearer.}

\author{
Specific Character.
}

Mas.-Capite viridi, semi-cristato ; rectricibus tribus externis utrinque albis.

Male.-Head, throat, chest, all the upper surface of the body, wing- and tail-coverts deep bronzy green, the green hue prevailing on the lower part of the back; wings black; under surface of the body and under tail-coverts deep blood-red; thighs black; four centre tailfeathers black ; the three outer ones black at the base, and white for the remainder of their length, with black shafts ; bill bright yellow.

Total length, $13 \frac{3}{4}$ inches ; bill, 1 ; wing, $7 \frac{1}{4} ;$ tail, $7 \frac{1}{4}$.

Female.-Head and chest brown, the latter washed with green; wing-coverts and back reddish green ; upper tail-coverts golden green ; wings black ; primaries brownish black, margined with buff; lower part of the abdomen and under tail-coverts light blood-red; tail black, the three outer feathers on each side toothed on their outer webs and narrowly tipped with greyish white.

Trogon Antisianus, D’Orb. Mag. de Zool. 1837, Ois. pl. 85.

antisiensis, D’Orb. Voy. de l'Am., p. 381. pl. 86. f. 1.

(Calurus) pulchellus, Gould, Mon. of Trog., List of Plates, sp. 22

pulchellus, Gould, Mon. of Trog., pl. 22.

Peruvianus, Gould, MSS.

Calurus antisianus, Gray and Mitch. Gen. of Birds, vol. i. p. 71, Calurus, sp. 7.-Ib. List of Spec. of Birds in Coll. Brit. Mus., part ii. sect. 1, Fissirostres, p. 46.-Sclater in Proc. of Zool. Soc., part xxiii. p. $13 \%$. pulchellus, Bonap. Consp. Gen. Av., p. 152, Calurus, sp. 6.

IT would appear that science is indebted to M. Alcide D'Orbigny, the celebrated French traveller, for the discovery of this exceedingly beautiful species ; for it was in his collection that I first saw an example during my visit to Paris in 1837. At that time the female was unknown, nor had it been discovered when the first edition of this monograph was published. In the interval between 1837 and 1858 many novelties have been obtained, not only in this group of birds, but in most other departments of zoology and the allied sciences, and I am now, therefore, enabled to figure both sexes of this fine bird, and to state that it not only inhabits Peru, but that it is also found in Ecuador, and as far south as Santa Fe de Bogota in New Grenada, as is proved by my having at this moment before me a specimen from the latter province, and another sent me by Professor Jameson from Quito : in all probability Bogota is its utmost northern limit, and Ecuador and Peru its true and native habitat. It is without question a truly beautiful species, the bright raised tuft of green feathers which rise above the nostrils adding much to its elegance, and, together with the all but wholly white outer tail-feathers, at once distinguishing it from the $P$. fulgidus.

"We have met with this species," says M. D'Orbigny, " in the midst of the hot and humid forests of the Yungas to the east of the Andes in the republic of Bolivia : there it is always rare, and almost entirely confined to the neighbourhood of the torrents in the thickest parts of the woods. Its manners, like those of the other members of the genus to which it belongs, are melancholy and wild. One often hears in the morning and in the evening its monotonous cry, which nearly resembles the word Couroucou; but how many difficulties are there to be conquered before one can reach this bird in the midst of a country perhaps the most unfrequently visited of the world!"”

The Plate represents both sexes of the size of life. 


\section{$2 \mathrm{BHL}$ Biodiversity Heritage Library}

Gould, John. 1858. "Beautiful Train-bearer, Pharomacrus antisianus." $A$ monograph of the Trogonidae or trogons 1, -. https://doi.org/10.5962/p.323612.

View This Item Online: https://www.biodiversitylibrary.org/item/264251

DOI: https://doi.org/10.5962/p.323612

Permalink: https://www.biodiversitylibrary.org/partpdf/323612

\section{Holding Institution}

Harvard University, Museum of Comparative Zoology, Ernst Mayr Library

\section{Sponsored by}

Harvard University, Museum of Comparative Zoology, Ernst Mayr Library

\section{Copyright \& Reuse}

Copyright Status: Public domain. The BHL considers that this work is no longer under copyright protection.

This document was created from content at the Biodiversity Heritage Library, the world's largest open access digital library for biodiversity literature and archives. Visit BHL at https://www.biodiversitylibrary.org. 